\title{
Hubungan Electronic Word of Mouth dan Hedonic Shopping Motivation dengan Perilaku Konsumtif Produk Make Up pada Mahasiswi
}

\author{
Ayu Kusumaningrum¹, Bagus Wicaksono', Rahmah Saniatuzzulfa ${ }^{1}$ \\ ${ }^{1}$ Program Studi Psikologi Fakultas Kedokteran Universitas Sebalas Maret \\ email:rsaniatuzzulfa@gmail.com
}

\begin{abstract}
Abstrak
Perkembangan tren make up mendorong mahasiswi ikut membeli produk make up terbaru tanpa mempertimbangkan kebutuhan. Penelitian ini bertujuan untuk mengetahui hubungan electronic word of mouth dan hedonic shopping motivation dengan perilaku konsumtif terhadap produk make up. Penelitian dilakukan pada 61 mahasiswi Psikologi Universitas Sebelas Maret yang dipilih menggunakan simple random sampling. Instrumen penelitian ini adalah skala perilaku konsumtif, skala electronic word of mouth, dan skala hedonic shopping motivation. Analisis data dilakukan dengan teknik analisis regresi ganda.Hasil penelitian menunjukkan nilai $p=0,000(p<0,05)$, artinya terdapat hubungan positif yang signifikan antara electronic word of mouth dan hedonic shopping motivation dengan perilaku konsumtif terhadap produk make up. Secara parsial, terdapat hubungan positif yang signifikan antara electronic word of mouth dengan perilaku konsumtif terhadap produk make up $(p=0,000<0,05)$ dan terdapat hubungan positif yang signifikan antara hedonic shopping motivation dengan perilaku konsumtif terhadap produk make up $(p=0,006<0,05)$. Nilai R2 sebesar 0,381 , menunjukkan bahwa electronic word of mouth dan hedonic shopping motivation secara bersamasama memberikan sumbangan efektif sebesar $38,1 \%$ pada perilaku konsumtif terhadap produk make up.
\end{abstract}

Kata kunci: electronic word of mouth; hedonic shopping motivation; mahasiswa; make up; perilaku konsumtif

\section{Relationship between Electronic Word of Mouth and Hedonic Shopping Motivation with Consumable Behavior of Make Up Products for Students}

\begin{abstract}
The makeup trends encourage female university students to buy the latest makeup products without considering their actual needs. This study aims to identify relation between electronic word of mouth and hedonic shopping motivation with consumptive behavior towards makeup products. This research was conducted on 61 female psychology majors of Sebelas Maret University, selected by using simple random sampling method. The research instruments consisted of consumptive behavior scale, electronic word of mouth scale, and hedonic shopping motivation scale. Data analysis used multiple regression analysis technique. Result shows the score of $p=0,000(p<0,05)$, which means that there is a significant, positive correlation between electronic word of mouth and hedonic shopping motivation with consumptive behavior toward makeup products. Partially, there is a significant, positive correlation between electronic word of mouth with consumptive behavior toward makeup products and also between hedonic shopping motivation with consumptive behavior toward makeup products hedonic shopping motivation with consumptive behavior toward makeup products. R2 score is 0,381 , which shows that both electronic word of mouth and hedonic shopping motivation give effective contribution of $38,1 \%$ to consumptive behavior toward makeup products.
\end{abstract}

Keywords: consumptive behavior; electronic word of mouth; hedonic shopping motivation; make up; student collage 


\section{Pendahuluan}

Di era milenial saat ini, mahasiswa tidak hanya dikenal sebagai agen perubahan di masyarakat, tetapi juga sebagai follower tren yang terjadi di masyarakat. Berbagai tren di masyarakat yang terus berkembang, mulai dari tren ekonomi, sosial, politik, teknologi, hingga busana dan kecantikan, tidak luput dari perhatian mahasiswa. Mahasiswa yang mengikuti tren kecantikan, khususnya tren produk make up, didominasi oleh kalangan mahasiswi.

Menurut Kartono (2007), mahasiswi berada di usia tahap perkembangan remaja akhir (usia 18-21 tahun) yang sedang menempuh pendidikan tinggi di Universitas. Mahasiswi sebagai bagian dari kalangan remaja, dianggap sebagai pembeli potensial untuk produk-produk, seperti pakaian, sepatu, makanan, minuman, dan kosmetik (Monks, Knoers, \& Haditono, 20014). Hal ini dikarenakan mahasiswi memiliki lebih banyak kebebasan dalam mengekspresikan diri di lingkungan kampus dibandingkan siswi sekolah, termasuk dalam penggunaan make up.

Survei Indonesia Hottest Insight 2012 yang dilakukan oleh Gramedia Majalah terhadap 3.000 perempuan (dalam Zakiya, 2012), menemukan bahwa perempuan Indonesia mulai eksploratif, yaitu mulai gemar membeli dan mencoba berbagai jenis make up ketika menginjak usia 20 tahun ke atas. Temuan ini menunjukkan bahwa kebanyakan perempuan Indonesia mulai cenderung berperilaku konsumtif terhadap produk-produk make up, ketika mereka berada di usia yang sama dengan usia kebanyakan remaja putri yang berstatus mahasiswi.

Menurut Rahayu (2016), besarnya peningkatan pasar kosmetik Indonesia, mendorong pemerintah membuat Peraturan Pemerintah Nomor 14 Tahun 2015 tentang rencana Induk Pembangunan Nasional (RIPIN) Tahun 2015-2035. Industri kosmetik menjadi salah satu Industri Andalan, yaitu industri prioritas yang berperan besar sebagai penggerak utama perekonomian. Potensi Indonesia untuk menjadi pasar utama pertumbuhan industri kecantikan ini didukung oleh konsumen-konsumen baru dari kalangan remaja tingkat akhir, khususnya kalangan mahasiswi yang baru mengenal penggunaan make up di lingkungan kampus.

Berdasarkan hasil pengumpulan data awal melalui survei online terhadap 57 mahasiswi di Universitas Sebelas Maret (UNS) menunjukkan bahwa selain aktif dalam menggunakan produk make up di kampus, para mahasiswi juga aktif membeli make up setiap 1 hingga 2 bulan sekali, dan memiliki lebih dari satu aitem untuk jenis produk make up yang sama. Mahasiswi tidak hanya mengetahui tren make up dari teman maupun lingkungan sekitar, tetapi juga dari berbagai situs internet. Kemudahan akses internet memudahkan mahasiswi dalam mengetahui informasi produk, bahkan memungkinkan mahasiswi untuk membeli produk secara online. Fasilitas praktis dari kemajuan teknologi ini akhirnya semakin mengembangkan kecenderungan mahasiswi untuk membeli dan mencoba berbagai produk make up baru. Kecenderungan mahasiswi untuk membeli produk-produk make up di luar kebutuhan tidak hanya dapat membuat mahasiswi menjadi boros, tetapi juga berperilaku konsumtif. Perilaku konsumtif menurut Fromm (2008b) adalah bentuk perilaku konsumen yang membuat individu melakukan pembelian secara berlebihan guna memenuhi kesenangan dan kebahagiaan yang hanya sementara.

Perempuan seringkali dianggap memiliki kecenderungan perilaku konsumtif yang lebih besar daripada laki-laki. Budianti, seorang psikolog (dalam Tabloid Nova, 2015), menyatakan bahwa alasan wanita bersifat lebih boros dibandingkan pria dikarenakan sensitivitas wanita yang lebih tinggi dibandingkan dengan pria. Budianti menambahkan, sensitivitas wanita yang tinggi dapat dilihat dari reaksi wanita yang lebih mudah tertarik ketika melihat barang-barang yang unik hingga barang yang sedang diskon.

Kotler (2009) menyebutkan beberapa faktor yang mempengaruhi perilaku konsumtif, dua diantaranya adalah opinion leader dan motivasi. Opinion leader di era digital dapat menyebarluaskan informasi melalui berbagai macam konten digital di internet yang dapat 
dilihat oleh seluruh masyarakat. Oleh sebab itu, informasi yang diberikan oleh opinion leader lewat internet dapat tersebar secara luas dan akhirnya menjadi electronic word of mouth (e-WOM).

Electronic word of mouth adalah pernyataan yang dibuat oleh konsumen mengenai suatu produk yang pernah ia gunakan dan dapat diakses oleh berbagai orang dan institusi di seluruh dunia melalui internet (HennigThurau, et. al, 2004). Kemudahan yang dimiliki konsumen dalam mengakses review suatu produk melalui electronic word of mouth yang disebarluaskan di internet, membuat konsumen saat ini lebih percaya pada electronic word of mouth dibandingkan informasi produk yang terdapat pada iklan resmi produk tersebut (Erkan \& Evans, 2016).

Penelitian sebelumnya terkait electronic word of mouth yang dilakukan oleh Apriani \& Pradana (2017) terhadap pelanggan Bakso Boedjangan di Bandung, menunjukkan bahwa electronic word of mouth berpengaruh signifikan terhadap keputusan pembelian. Penggunaan electronic word of mouth yang sangat berpengaruh terhadap para pelanggan Baso Boedjangan adalah melalui rekomendasi lewat akun media sosial. Bentuk electronic word of mouth yang disebarkan lewat media sosial adalah salah satu bentuk electronic word of mouth yang cepat tersebar luas dan dapat dilihat oleh banyak orang di berbagai situs internet.

Kehadiran electronic word of mouth tidak hanya ada pada industri kuliner, tetapi juga sudah merambah industri kecantikan. Hal ini dapat dilihat dari semakin banyaknya blog dan situs internet yang menyediakan review produk kecantikan, khususnya make up. Menurut Kathy Wrennall, pendiri social media marketing agency Not Just Powder (dalam Hardy, 2016), 74\% konsumen mengandalkan media sosial dalam memutuskan pembelian produk kecantikan.

Selain pengaruh dari opinion leader lewat electronic word of mouth yang tersebar secara luas, kemunculan perilaku konsumtif juga dipengaruhi oleh motivasi atau dorongan dari diri individu. Motivasi individu dalam memilih dan membeli suatu produk menjadi alasan kuat yang mendorong individu untuk berbelanja. Berbeda dengan utilitarian shopping motivation yang mendorong konsumen untuk berbelanja karena nilai-nilai instrumental dari fungsi produk suatu brand tertentu (Batra dalam Rahmawati \& Do, 2014), hedonic shopping motivation adalah motivasi belanja yang didorong oleh alasan-alasan intrinsik, multisensory, fantasi, dan aspekaspek emosional yang dipegang oleh individu dalam memenuhi kebutuhan (Arnold \& Reynolds, 2003).

Penelitian sebelumnya terkait hedonic shopping motivation yang dilakukan oleh Arnold \& Reynolds (2003) terhadap 33 lakilaki dan 55 perempuan berusia 18-55 tahun yang berasal dari latar belakang pekerjaan dan tingkat pendapatan yang beraneka ragam, menghasilkan enam kategori hedonic shopping motivation, yang terdiri dari: adventure shopping, social shopping, gratification shopping, idea shopping, role shopping, dan value shopping. Perbedaan dari keenam kategori hedonic shopping motivation tersebut terletak pada tujuan utama dari kegiatan berbelanja yang dilakukan individu.

Penelitian hedonic shopping motivation lain yang dilakukan oleh Pasaribu \& Dewi (2015) terhadap 100 responden konsumen online store Zalora, dengan $80 \%$ diantaranya adalah mahasiswi, menunjukkan salah satu faktor yang mendorong responden untuk berbelanja online adalah hedonic shopping motivation, dengan rata-rata persentase skor hedonic shopping motivation sebesar $72 \%$. Persentase yang termasuk tinggi ini menjadikan hedonic shopping motivation sebagai salah satu hal yang dipertimbangkan produsen dalam memasarkan produk kepada konsumen.

Tujuan penelitian ini untuk meneliti hubungan antara electronic word of mouth dan hedonic shopping motivation dengan perilaku konsumtif terhadap produk make up pada mahasiswi Program Studi Psikologi, Fakultas Kedokteran, Universitas Sebelas Maret. 


\section{Metode}

Subjek penelitian ini adalah mahasiswi Program Studi Psikologi Universitas Sebelas Maret (UNS) dari angkatan 2015 dan 2016. Teknik pengambilan sampel menggunakan teknik simple random sampling.

Penelitian ini merupakan penelitian kolerasional sehingga peneliti menggunakan instrumen meliputi skala perilaku konsumtif, skala electronic word of mouth dan skala hedonic shopping motivationdengan skala model Likert yang memiliki empat kemungkinan jawaban yaitu sangat sesuai (SS), sesuai (S), tidak sesuai (TS) dan sangat tidak sesuai (STS).

\section{Skala Perilaku Konsumtif}

Skala perilaku konsumtif dimodifikasi dari skala yang disusun oleh Rengganis (2016) berdasarkan aspek-aspek dari Fromm (2008a) yang terdiri dari: pemenuhan keinginan, barang di luar jangkauan, barang tidak produktif, dan status. Hasil uji coba menunjukkan 29 aitem valid pada rentang indeks daya beda antara 0,287 sampai 0,631 dengan koefisien reliabilitas $(\alpha)=0,901$.

\section{Skala Electronic Word of Mouth}

Skala electronic word of mouth menggunakan skalayang dikembangkan oleh peneliti berdasarkan dimensi-dimensi electronic word of mouth yang dikemukakan oleh Cheung \& Thandani (2010). Dimensi-dimensi tersebut terdiri dari: kualitas argumen, recommendation framing (valence), recommendation rating, panjang review, purchase intention, dan interest in productHasil uji coba menunjukkan 34 aitem valid pada rentang indeks daya beda antara 0,304 sampai 0,730 dengan koefisien reliabilitas $(\alpha)=0,934$.

\section{Skala Hedonic Shopping Motivation}

Skala hedonic shopping motivationmenggunakan skala yang diadaptasi dari skala hedonic shopping motivation dari Arnold \& Reynolds (2003). Hasil uji coba menunjukkan 15 aitem valid pada rentang indeks daya beda antara 0,306 sampai dengan 0,704 dengan koefisien reliabilitas $(\alpha)=0,849$.
Penelitian ini menggunakan analisis regresi berganda yang sebelumnya dilakukan uji asumsi dasar dan uji asumsi klasik. Perhitungan analisis data menggunakan program Statistical Product and Service Solution (SPSS) versi 20.0.

\section{Hasil}

\section{Uji Asumsi Dasar dan Klasik}

Uji asumsi dasar meliputi uji normalitas dan uji linearitas. Hasil Berdasarkan uji normalitas pada skala perilaku konsumtif, electronic word of mouth, dan hedonic shopping motivation menggunakan One-Sample Kolmogrov-Smirnov Testmasing-masing yaitu 0,$751 ; 0,653 ; 0,228$ dengan nilai $p>0,05$, maka dapat disimpulkan data ketiga variabel terdistribusi secara normal.

Hasil Uji linearitas menunjukkan nilai $p<0,05$ sehingga dapat disimpulkan bahwa terdapat hubungan secara linear antara electronic word of mouth dengan perilaku konsumtif dan hedonic shopping motivationkematangan emosi dengan perilaku konsumtif. Uji Asumsi Klasik meliputi uji multikolinearitas, uji heteroskedastisitas dan uji autokolerasi. Hasil uji multikolinearitas antar variabel prediktor yaitu nilai Variance Inflation Factor $(\mathrm{VIF})=1,080$ dan Tolerance $=0,926$. Berdasarkan hasil tersebut menunjukkan bahwa nilai VIP $<5$ dan Tolerance $\geq 0,10$ sehingga dapat disimpulkan bahwa antar variabel bebas tidak terjadi multikolinearitas.

Hasil Uji heteroskedastisitas menunjukkan bahwa titik-titik data menyebar secara tidak beraturan dan tidak berpola. Hal ini menunjukkanmodel regresi bebas dari asumsi heteroskedatisitas.

Hasil uji autokolerasi menunjukkan nilai nilai Dusbin-Watson $(D W)=1,572$, signifikansi 0.05 dengan $n$ (jumlah data) $=61$ dan $\mathrm{k}$ (jumlah variabel independen) $=2$ didapatkan nilai DU adalah 1,619. Berdasarkan nilai DW $(1,572)$ terletak diantara DU $(1,619)$ dan 4-DU (2,381). Berdasarkan hal tersebut dapat disimpulkan bahwa tidak terjadi autokolerasi. 
Uji Hipotesis

Tabel 1. Uji Simulan (F) ANOVAa

\begin{tabular}{lllllll}
\hline Model & Sum of Squares & df & Mean Square F & Sig. \\
\hline \multirow{2}{*}{1} & Regression & 3018,689 & 2 & 1509,345 & 17,834 &, $000 \mathrm{~b}$ \\
& Residual & 4908,721 & 58 & 84,633 & & \\
& Total & 7927,410 & 60 & & & \\
\hline
\end{tabular}

a. Dependent Variable: Perilaku Konsumtif

b. Predictors: (Constant), Hedonic Shopping Motivation, Electronic Word of Mouth

Berdasarkan perhitungan, Fhitung yang diperoleh sebesar 17,834 dengan Ftabel sebesar 3,156, maka dapat disimpulkan Fhitung $>$ Ftabel, dengan nilai signifikasi $p<$ 0,05 . Berdasarkan hasil tersebut dapat disimpulkan bahwa hipotesis 1 diterima yaitu terdapat hubungan antara electronic word of mouth, dan hedonic shopping motivation dengan perilaku konsumtif terhadap produk make up pada mahasiswi Psikologi Universitas Sebelas Maret.

Uji Korelasi

Uji hipotesis 2 dan 3 menggunakan uji hipotesis korelasi parsial. Uji hipotesis 2 dan 3 untuk mengetahui hubungan salah satu variabel bebas dengan variabel terikat.

Tabel 2. Hasil Uji Korelasi Parsial oleh Electronic Word of Mouth, Hedonic Shopping Motivation dengan Perilaku Konsumtif

\begin{tabular}{|c|c|c|c|c|}
\hline Control Variables & & & PK & EWOM \\
\hline \multirow[t]{6}{*}{ HSM } & PK & Correlation & 1,000 & ,488 \\
\hline & & \multicolumn{3}{|c|}{ Significance (2-tailed) .000 } \\
\hline & & Df & 0 & 58 \\
\hline & EWOM & Correlation & ,488 & 1,000 \\
\hline & & Significance (2-tailed) &, 000 & \\
\hline & & $\begin{array}{l}\text { Df } \\
\text { Correlations }\end{array}$ & 58 & 0 \\
\hline Control Variables & & & PK & HSM \\
\hline \multirow[t]{6}{*}{ EWOM } & PK & Correlation & 1,000 & .354 \\
\hline & & \multicolumn{2}{|c|}{ Significance (2-tailed) } & ,006 \\
\hline & & Df & 0 & 58 \\
\hline & HSM & Correlation & ,354 & 1,000 \\
\hline & & \multicolumn{3}{|c|}{ Significance (2-tailed),006 } \\
\hline & & & 58 & 0 \\
\hline
\end{tabular}


Berdasarkan hasil tersebut menunjukkan nilai korelasi 0,488 dengan nilai signifikansi sebesar $0,000 \quad(p<0,05)$. Dengan demikian dapat disimpulkan bahwa hipotesis kedua dalam penelitian ini dapat diterima, yaitu terdapat hubungan yang signifikan antara electronic word of mouth dengan perilaku konsumtif terhadap produk make up pada mahasiswi Psikologi Universitas Sebelas Maret.

Berdasarkan hasil tersebut menunjukkan nilai korelasi 0,354 dengan nilai signifikansi sebesar 0,006 ( $p<0,05)$. Dengan demikian dapat disimpulkan bahwa hipotesis ketiga dalam penelitian ini dapat diterima, yaitu terdapat hubungan yang signifikan antara hedonic shopping motivation dengan perilaku konsumtif terhadap produk make up pada mahasiswi Psikologi Universitas Sebelas Maret.

\section{Analisis Deskriptif}

Berikut ini merupakan hasil kategorisasi setiap variabel.

Tabel 3 Kriteria dan Kategori RespondePenelitian

\begin{tabular}{lllll}
\hline Variabel & \multicolumn{2}{l}{ Kategorisasi } & Norma & \multicolumn{2}{c}{ Jumlah Responden } \\
& & & F $\%$ \\
\hline \multirow{2}{*}{ Perilaku Konsumtif } & Rendah & $29 \leq X<58$ & 22 & $36,07 \%$ \\
& Sedang & $58 \leq X<87$ & 38 & $62,30 \%$ \\
& Tinggi & $87 \leq X \leq 116$ & 1 & $1,63 \%$ \\
& & & & \\
Electronic Word of Mouth & Rendah & $34 \leq X<68$ & 1 & $1,64 \%$ \\
& Sedang & $68 \leq X<102$ & 57 & $93,44 \%$ \\
Hedonic Shopping & Tinggi & $102 \leq X \leq 136$ & 3 & $4,92 \%$ \\
Motivation & & & & \\
& Rendah & $15 \leq X<30$ & 4 & $6,56 \%$ \\
& Sedang & $30 \leq X<45$ & 51 & $83,60 \%$ \\
& Tinggi & $45 \leq X \leq 60$ & 6 & $9,84 \%$ \\
\hline
\end{tabular}

Koefisien determinasi (R2) dalam penelitian ini adalah sebesar 0,381 . Hasil tersebut menunjukkan bahwa persentase sumbangan pengaruh yang diberikan electronic word of mouth dan hedonic shopping motivation terhadap perilaku konsumtif adalah sebesar $38,1 \%$ dengan sisa $61,9 \%$ dipengaruhi oleh faktor lain yang tidak diteliti.

Kontribusi electronic word of mouth dan hedonic shopping motivation dengan perilaku konsumtif bersama-sama adalah 38,1 persen dengan kontribusi electronic word of mouth sebesar 24,7 persen dan hedonic shopping motivation sebesar 13,4 persen.

\section{Pembahasan}

Berdasarkan hasil uji hipotesis menunjukkan perhitungan, Fhitung yang diperoleh sebesar 17,834 dengan Ftabel sebesar 3,156, maka dapat disimpulkan Fhitung $>$ Ftabel, dengan nilai signifikasi $p<0,05$. Berdasar- an hasil tersebut dapat disimpulkan bahwa hipotesis 1 diterima yaitu terdapat hubungan antara electronic word of mouth, dan hedonic shopping motivation dengan perilaku konsumtif terhadap produk make up pada mahasiswi Psikologi Universitas Sebelas Maret.

Hasil ini menunjukkan selain terjadi hubungan positif yang signifikan, hubungan antara electronic word of mouth dan hedonic shopping motivation dengan perilaku konsumtif digolongkan dalam hubungan yang kuat. Semakin tinggi pengetahuan mahasiswi mengenai electronic word of mouth yang menyertai produk diikuti dengan semakin tingginya hedonic shopping motivation pada diri mahasiswi, maka akan semakin tinggi perilaku konsumtif yang ditunjukkan mahasiswi.

Hasil penelitian ini mendukung penelitian terdahulu yang dilakukan oleh Poyry, Parvinen, Salo, \& Blakaj (2012) yang menemukan adanya hubungan antara pencarian informasi yang didorong oleh motivasi hedonis 
dengan pencarian electronic word of mouth yang bermanfaat.Konsumen yang mencari review produk dengan pengaruh dorongan motivasi hedonis tidak terlalu banyak mencari review lain setelah mereka mendapatkan informasi produk dari review yang dianggap sudah memberikan informasi yang mereka cari. Hal ini membuat konsumen menjadi lebin cepat dalam memutuskan untuk membeli suatu produk karena mereka memilih untuk hanya membaca review yang dianggap memuaskan keingintahuan mereka mengenai produk tersebut.

Menurut Kotler (2009), kemunculan perilaku konsumtif dapat terjadi sebagai pengaruh dari beberapa faktor, yaitu: lifecycle stage (usia dan tahap siklus kehidupan), pekerjaan dan keadaan ekonomi, gaya hidup, konsep diri, kepribadian, motivasi individu, pembelajaran, keyakinan, budaya, sub-budaya, kelas sosial, status, keluarga, teman, kelompok referensi, dan opinion leader. Awalnya, yang dikenal sebagai opinion leader adalah sosok-sosok public figure maupun orang-orang yang memiliki pengetahuan dalam bidang tertentu dan sudah banyak dikenal masyarakat. Hal tersebut berbeda dengan situasi saat ini, ketika semua orang mampu menjadi opinion leader melalui berbagai situs dan platform media sosial yang terbuka untuk umum sebagai mengekspresikan pendapat dalam ranah dunia maya.

Keberadaan berbagai online platform dan pengaruh kemunculan banyaknya beauty influencer semakin mendorong banyak individu untuk juga ikut menyuarakan pendapat mereka tentang suatu produk make up melalui review produk di situs reviewmake up, blog, hingga akun media sosial pribadi. Pendapat individu dan interaksi mereka dengan individu-individu lain di internet mengenai performa produk make up dan pengalaman mereka dalam menggunakan produk tersebut, yang tersebar secara online ini menjadi electronic word of mouth (e-WOM) yang dapat diakses oleh semua orang dan dijadikan acuan bagi orang lain dalam menilai suatu produk make up, baik sebagai referensi informasi produk, maupun acuan sebelum membuat keputusan pembelian.

Sebagai salah satu faktor yang mempengaruhi perilaku konsumtif, motivasi seringkali dianggap sebagai inisiasi dan pen- garahan tingkah laku manusia (Moskowits dalam Setiadi, 2013). Motivasi konsumen sendiri terbentuk sebagai pengarah individu dalam melakukan kegiatan konsumsi untuk mencapai tujuan dan kepuasan yang diinginkan individu dari konsumsi barang tersebut. Motivasi yang mendorong perilaku konsumsi pada individu ini membuat individu berusaha untuk memenuhi kebutuhan konsumsinya, salah satunya dengan cara berbelanja. Kegiatan belanja yang dilakukan oleh individu dapat didorong oleh nilai-nilai fungsional dari barang yang dibeli (utilitarian) dan juga dari nilai-nilai hedonis, yaitu kehendak pribadi individu untuk mendapatkan kepuasan dari barang yang dibeli (hedonic).

Kegiatan belanja yang dilatarbelakangi oleh nilai-nilai hedonis yang mengutamakan kepuasan pribadi dibandingkan fungsi dari barang yang dikonsumsi ini didorong oleh hedonic shopping motivation pada diri individu. Individu yang memiliki hedonic shopping motivation yang tinggi menjadi lebih sering membeli produk-produk yang bukan menjadi kebutuhan utama dan tidak terlalu berfungsi bagi diri individu. Apabila berlangsung secara terus-menerus dalam waktu yang lama, pembelanjaan barang yang didorong oleh hedonic shopping motivation dapat merugikan diri individu terutama dalam segi finansial dan penggunaan fungsi produk.

Berdasarkan hasil uji korelasi parsial menunjukkan nilai korelasi 0,488 dengan nilai signifikansi sebesar $0,000(p<0,05)$. Dengan demikian dapat disimpulkan bahwa hipotesis kedua dalam penelitian ini dapat diterima, yaitu terdapat hubungan yang signifikan antara electronic word of mouth dengan perilaku konsumtif terhadap produk make up pada mahasiswi Psikologi Universitas Sebelas Maret.

Hasil penelitian ini mendukung penelitian terdahulu yang dilakukan oleh Al-Haidari \& Coughlan (2014) mengenai pengaruh electronic word of mouth terhadap pemahaman informasi dan keputusan pembelian konsumen dalam membeli produk kecantikan. Salah satu bentuk electronic word of mouth yang menyertai produk-produk make up dapat dilihat dari banyaknya review-review produk make up di internet yang dibagikan oleh para beauty influencer dan juga warganet. Individu akan lebih cenderung untuk membeli produk- 
produk make up yang memiliki banyak review positif dibandingkan produk make up yang memiliki banyak review negatif.

Selain itu, pengaruh electronic word of mouth terhadap preferensi konsumen mengenai produk pernah diteliti oleh Utami, Tanujaya, \& Jokom (2015) dan juga oleh Ishida, Slevitch, \& Siamionava (2016). Pengaruh dari electronic word of mouth ini dapat menyebabkan konsumen ikut membeli produk yang sebenarnya tidak cocok untuk dirinya, ataupun batal membeli produk yang memang dibutuhkan hanya karena kebetulan konsumen membaca review yang negatif, atau membeli produk yang dibutuhkan beserta produk lain yang menarik hati konsumen karena review positif dari produk tersebut, meskipun konsumen sudah memiliki produk serupa.

Uji korelasi parsial kedua menunjukkan nilai korelasi 0,354 dengan nilai signifikansi sebesar 0,006 $(p<0,05)$. Dengan demikian dapat disimpulkan bahwa hipotesis ketiga dalam penelitian ini dapat diterima, yaitu terdapat hubungan yang signifikan antara hedonic shopping motivation dengan perilaku konsumtif terhadap produk make up pada mahasiswi Psikologi Universitas Sebelas Maret.

Hasil penelitian ini mendukung penelitian terdahulu oleh Yu dan Basin (2010) dan juga Puspita \& Budiarti (2016) mengenai pengaruh hedonic shopping motivation terhadap pembelian impulsif yang merupakan salah satu bentuk perilaku konsumtif. Hedonic shopping motivation mendorong keinginan individu untuk dapat menghibur diri sekaligus bersenang-senang dengan cara berbelanja, baik sendirian maupun bersama-sama orang terdekat. Ketika berbelanja untuk menghibur diri individu seringkali membeli barang yang dilihat mampu memuaskan hatinya, tanpa mempertimbangkan hal-hal lain. Belanja bersama orang lain sering dianggap sebagai salah satu cara untuk bersosialisasi dengan orang baru dan juga dengan orang-orang terdekat.

Selain itu, penelitian Kang \& ParkPoaps (2010) menemukan bahwa keinginan untuk menemukan ide dan pengalaman baruyang dimotivasi oleh hedonic shopping motivation membuat konsumen terpengaruh untuk mencoba produk-produk terbaru. Konsumen tidak akan ragu untuk memesan produk yang belum mulai rilis di pasaran karena ingin men- dapatkan pengalaman dari menggunakan produk yang terbaru. Keinginan konsumen untuk berbelanja demi mencari kesenangan, ide, serta pengalaman yang baru ini seringkali membuat konsumen lupa untuk mempertimbangkan aspek efisiensi dan efektivitas dari produk yang dibeli.

Persentase sumbangan pengaruh yang diberikan electronic word of mouth dan hedonic shopping motivation terhadap perilaku konsumtif adalah sebesar 38,1\% dengan sisa $61,9 \%$ dipengaruhi oleh faktor lain yang tidak diteliti, misalnya kontrol diri, konformitas, citra merek, diskon, kepuasan konsumen, dan kepercayaan konsumen.

Kontribusi electronic word of mouth dan hedonic shopping motivation dengan perilaku konsumtif bersama-sama adalah 38,1 persen dengan kontribusi electronic word of mouth sebesar 24,7 persen dan hedonic shopping motivation sebesar 13,4 persen.

\section{Kesimpulan}

Berdasarkan hasil penelitian, maka dapat ditarik kesimpulan terdapat hubungan positif yang signifikan antara electronic word of mouth dan hedonic shopping motivation dengan perilaku konsumtif terhadap produk make up pada mahasiswi Psikologi Universitas Sebelas Maret, terdapat hubungan positif yang signifikan antara electronic word of mouth dengan perilaku konsumtif terhadap produk make up pada mahasiswi Psikologi Universitas Sebelas Maret, dan terdapat hubungan positif yang signifikan antara hedonic shopping motivation dengan perilaku konsumtif terhadap produk make up pada mahasiswi Psikologi Universitas Sebelas Maret.

Persentase total sumbangan efektif yang diberikan electronic word of mouth dan hedonic shopping motivation terhadap perilaku konsumtif adalah sebesar 38,1\%, sedangkan $61,9 \%$ sisanya dipengaruhi oleh faktor-faktor lain yang tidak diteliti dalam penelitian ini.

\section{Daftar Pustaka}

Apriani, D., \&Pradana, M. (2017). The Influence of Electronic Word of Mouth (Ewom) TowardsConsumers' Purcha- 
seDecisionat Bakso Boedjangan, Bandung. IJRDO-Journal of Business Management, 3, 38-44.

Arnold, M.J., \& Reynolds, K.E. (2003). HedonicShopping Motivations. Journal of Retailing, 79, 77-95.

Babin, B.J., Darden, W.R., \&Griffin, M. (1994). "Workand/orFun: Measuring Hedonicand Utilitarian Shopping Value". Journal of Consumer Research, 20, 91-100.

Cheung,C.M., \&Thandani, D.R. (2010). The Effectiveness of Electronic Word-of-MouthCommunication: A Literature Analysis. eTrust: Implications for the Individual, Enterprises, andSociety.23rd BledeConference (pp. 329- 345).

Hardy, L. (2016). Future of Beautyls LookingGood. Raconteur's The BeautyEconomy Special Report, $417,3$.

Hennig-Thurau, T., Gwinner, K.P., Walsh, G. \&Gremle, D.D. (2004). Electronic Word-Of-Mouth via ConsumerOpinion Platforms: What Motivates Consumersto Articulate Themselves on the Internet?. Journal of Interactive Marketing, 18, 38-52.

Ishida, K., Sleivitch, L., \& Siamionava, K. (2016). The Effects of Traditional and Electronic Word of Mouth on DestinationImage: A Case of vacation Tourists Visiting Branson, Missouri. Administrative Sciences, 6(12), 1-17.

Kang, J., \& Park-Poaps, H. (2010). Hedonicand Utilitarian Shopping Motivations of Fashion Leadership. Journal of Fashion Marketing and Management, 14(2), 312- 328.

Kartono, K. (2007). Psikologi Perkembangan Anak. Bandung : CV. Mandar.

Monks, F.J., Knoers, A.M.P., Haditono, S.R. (2014). Psikologi Perkembangan: Pengantar dalam Berbagai Bagian. Yogyakarta: Gadjah Mada Unversity Press.

Pasaribu, L.O., \& Dewi, C.K. (2015). Pengaruh Hedonic Shopping Motivation terhadap Impulse Buying pada Toko Online: Studi pada Toko Online Zalora. Bina Ekonomi, 19, 159169.
Poyry, E., Parvinen, P., Salo, J., \& Blakaj, H. (2012). Hedonicand Utilitarian Search for Electronic Word of Mouth. 45th Hawaii International Conference on System Sciences, 1797-1806.

Rahayu, E.M. (2016). Wow, Indonesia Pasar Pertumbuhan Utama Industri Kecantikan ASEAN. SWA Article. Dikutip dari lamanhttp://swa.co.id/ swa/business-strategy/wowindonesia-pasar-pertumbuhan-utamaindustri-kecantikan-asean

Rahmawati, \& Do, B.R. (2014). Shopping Motivation on Purchase Intention: CanLoyalty Program and Corporate Image Enhance Such Relationship?. Asia Pacific Management and Business Application, 2(3), 154-169.

Rengganis, N. (2016). Hubungan antara Stereotip Daya Tarik Fisik dan Kesepian dengan Perilaku Konsumtif terhadap Produk Kosmetik pada Mahasiswi Fakultas IImu Sosial dan IImu Politik Universitas Sebelas Maret. (Skripsi dipublikasikan). Surakarta: Universitas Sebelas Maret..

Setiadi, N.J. (2013). Perilaku Konsumen: Perspektif Kontemporer pada Motif, Tujuan, dan Keinginan Konsumen (Edisi Revisi). Jakarta: Kencana.

Utami, C. (2010). Manajemen Ritel Strategi dan Implementasi Operasional Bisnis Ritel Modern di Indonesia. Jakarta: Salemba Empat.

Utami, V.K., Tanujaya, D., \& Jokom, R. (2015). Analisa Faktor yang Penting dari Dimensi Electronis Word of Mouth (EWOM) Bagi Konsumen dalam Memilih Hotel di Situs Online Travel Agent (OTA). Jurnal Manajemen Pemasaran, 9(2),78-85.

Yu, C., \& Bastin, M. (2010). Hedonic Shopping Value and Impulse Buying Behavior in Transational Economies: A Symbiosis in the Mainland China Marketplace. Brand Management, 18 (2), 105-114.

Zakiya, Z. (2012). Perempuan RI Alami Perubahan Drastis di Usia Awal 20-an. National Geographic Indonesia Article. Dikutip dari lamanhttp://na- 
tionalgeographic.co.id/berita/2012/07/

drastis-di-usia-awal-20-an

perempuan-ri-alami-perubahan- 